\title{
Effect of prolactin and dopaminergic drugs on uterine response to chronic estrogen exposure
}

\author{
A G Gunin, V Emelianov, A S Tolmachev and A Tolmacheva \\ Department of Histology, Medical Institute, Chuvash State University, PO Box 86, Cheboksary, 428034, Russia \\ (Requests for offprints should be addressed to A G Gunin, PO Box 86, Cheboksary, 428034, Russia; Email: drgunin@yahoo.com)
}

\begin{abstract}
The aim of this work was to examine the role of prolactin and dopaminergic drugs, which affect prolactin secretion, on proliferative and morphogenetic reactions in the uterus under continuous estrogen treatment. Ovariectomized mice received injections of estradiol dipropionate $(2 \mu \mathrm{g}$ per $100 \mathrm{~g}$, weekly) or vehicle and daily injections of prolactin $(0.25 \mathrm{mg} / 100 \mathrm{~g})$ or saline $(0.05 \mathrm{ml})$ for 30 days. Other groups of mice received injections of estradiol or vehicle and injections of saline, and were allowed to drink bromocriptine $(25 \mathrm{mg} / \mathrm{l})$, metoclopramide $(25 \mathrm{mg} / \mathrm{l})$, or only tap water for 30 days. Prolactin administration results in a decrease in the incidence of abnormal glands with abnormal epithelium, the incidence of atypical hyperplasia, uterine weight, proliferation (the number of mitotic and bromodeoxyuridine-labeled cells) and the levels of estrogen receptor- $\alpha$, but causes an increase in the level of $\beta$-catenin in uterine tissues of estrogen-treated mice.
\end{abstract}

The effect of metoclopramide, which increases prolactin secretion, is principally similar to prolactin, but much less expressed. Bromocriptine, which reduces prolactin levels, increases uterine weight, proliferation, the levels of estrogen receptor- $\alpha$, the incidence of abnormal glands with abnormal epithelium, the incidence of complex and atypical hyperplasia, and decreases the level of $\beta$-catenin in uterine structures of estrogen-treated mice. In the absence of estradiol, none of the treatments used had any effect on the parameters tested. Thus, prolactin or metoclopramide produce antiestrogenic effects in the uterus of mice and prevent the formation of atypical hyperplasia which has an unfavorable prognosis, but bromocriptine has the opposite effect. Estrogen receptor- $\alpha$ and $\beta$-catenin were associated with the actions of prolactin, metoclopramide and bromocriptine on estrogen-dependent processes in the uterus.

Journal of Endocrinology (2002) 172, 61-69

\section{Introduction}

Prolactin and dopaminergic drugs which alter the level of prolactin have been shown to affect the uterine response to estrogens. One group of data showed that prolactin or metoclopramide-induced hyperprolactinemia reduced estrogen-dependent proliferation and growth in the uterus or promoted the development of endometrial tumors (Kimura et al. 1986, Imai et al. 1993, Gunin 1996, Spritzer et al. 1996). Other observations did not reveal any prolactin influence on estrogen-dependent processes in the uterus (Hernandez \& Alvarez 1980, Kiss et al. 1987, Borgundvaag et al. 1992). It has also been documented that prolactin augmented estrogen-stimulated events in the uterus (Hernandez \& Alvarez 1980, Ohno 1982, Singtripop et al. 1991, Kelly et al. 1997). However, all experimental work in this area utilized acute estrogen treatment that could only produce some of the estrogen effects on the uterus. These effects mainly include increases in uterine weight, proliferation and cell growth. Other estrogen-induced effects in the uterus comprise morphogenetic alterations and include changes in the type of luminal and glandular epithelia, the number and shape of glands, and the morphology of epithelial cells, that are related to hyperplasia and cancer formation (Martin et al. 1973, Deligdisch 2000, Silverberg 2000). These morphogenetic effects are expressed and can be seen only under chronic estrogen exposure, but not in the short-term (Martin et al. 1973, Gunin 1998, Gunin et al. 2001). There are no studies using long-term estrogen treatments in this area of research.

Thus, there is no reliable experimental evidence as to whether prolactin plays a role in the formation of hyperplastic or neoplastic changes in the uterus. Clinical data are also controversial. Some groups support the idea that prolactin is involved in the formation of endometrial cancer (which is estrogen-dependent) (Barnes et al. 1981, Lipsett 1983, Ristic et al. 1986, Dexeus \& Barri 1998, Emons et al. 2000), while others do not (Lucas \& Yen 1979, Ylikorkala et al. 1979, Marchesoni et al. 1982, Falsetti et al. 1983, Kauli et al. 1985, Tolino et al. 1991). Therefore, the aim of the present work was to examine 
how prolactin and drugs which change the prolactin levels in the organism affect the uterine response to longterm estradiol administration. Expression of estrogen receptor- $\alpha$, which is known to limit the uterine response to estradiol (Couse \& Korach 1999), was analyzed in this work together with classical histological and proliferative parameters. $\beta$-Catenin, a component of both adhesion junctions and the Wnt-signaling pathway, was shown to be affected by estrogens and to play a role in endometrial carcinogenesis (Fujimoto et al. 1998, Miyamoto et al. 2000). The distribution and level of expression of $\beta$-catenin were therefore analyzed in this study.

\section{Materials and Methods}

\section{Animals}

All procedures were performed in accordance with the Guidelines on the Handling and Training of Laboratory Animals, published by the Universities Federation for Animal Welfare, and with the Chuvash State University Rules for Work with Laboratory Animals. White nonlinear female mice (20-22 g) were used. Animals were obtained from the Animal Department of Chuvash State University (Cheboksary, Russia) and were housed with free access to water and food. Mice were ovariectomized 1 week before the experiments were started. All surgical procedures were performed under anesthesia with ketamine and droperidol $(70 \mathrm{mg} / \mathrm{kg}$ and $0.1 \mathrm{mg} / \mathrm{kg}$ respectively, i.p.; Gedeon-Richter, Budapest, Hungary).

\section{Treatments}

Ovariectomized mice received subcutaneous injections of estradiol dipropionate in olive oil (Minmedprom, RostovDon, Russia) at a dose of $2 \mu \mathrm{g}$ per $100 \mathrm{~g}$ body weight, or vehicle once a week and daily injections of ovine prolactin $(0.25 \mathrm{mg} / 100 \mathrm{~g}$, s.c.; kindly provided by Dr A F Parlow, National Hormone and Pituitary Program, Harbor-UCLA Medical Center, Torrance, CA, USA) or vehicle $(0.05 \mathrm{ml}$ per mouse, $0.9 \%$ sodium chloride) for 30 days. Other groups of mice received injections of estradiol or olive oil, daily injections with $0.9 \%$ sodium chloride and drank tap water or water containing bromocriptine $(25 \mathrm{mg} / \mathrm{l}$; Novartis Pharma, Basel, Switzerland) or metoclopramide (25 mg/l; ArzneimitelWerk, Dresden, Germany) for 30 days. Water intake was monitored throughout the experiment, and doses of drugs were then calculated; these were approximately $0.42 \mathrm{mg}$ bromocriptine and $0.4 \mathrm{mg}$ metoclopramide per $100 \mathrm{~g}$ body weight per day. The dose of estradiol used had previously been shown to induce specific changes in the uterus (Gunin et al. 2001). It has also been shown that treatment with prolactin, metoclopramide, or bromocriptine, which were used in the same manner and at approximately the same doses as in the present study, was able to induce hyper- (prolactin, metoclopramide) or hypoprolactinemia (bromocriptine) (Advis et al. 1981, Shaban \& Terranova 1986, Marubayashi et al. 1989, Kawagoe \& Hiroi 1989). Two hours before the tissues were removed, all animals were injected intraperitoneally with $5 \mathrm{mg}$ bromodeoxyuridine (BrdU; Sigma Chemical Co., St Louis, MO, USA) per $100 \mathrm{~g}$ body weight dissolved in saline. There were 20 mice in each estradiol-treated group and 5 mice in each olive oil-treated group. The uteri were removed on the third day after the last estradiol or vehicle injection. The middle segment of the uterine horns was removed under deep ether anesthesia. Uteri were weighed and then placed in modified Bouin's fixative (Gunin et al. 2000) for $6 \mathrm{~h}$ at room temperature, and were then dehydrated and embedded in paraffin. Uteri were transversely orientated and cut at $5-7 \mu \mathrm{m}$.

\section{Uterine histology}

Histological changes in the uterus were analyzed and diagnosed according to Scully et al. (1994). To estimate the extent of any hyperplastic or neoplastic changes in the endometrium, uterine glands were subdivided into 4 morphological types: (1) normal glands; (2) cystic glands; (3) glands with daughter glands; (4) conglomerate of glands, as described in Gunin et al. (2001). The number of each type of gland was calculated in randomly selected sections. At least 3 sections from each animal were examined. Results are expressed as the percentage of each type of gland. The epithelium of all glands in randomly selected sections was examined and typed as simple, pseudostratified or stratified (multilayered) epithelia. The percentage of glands with each type of epithelium was calculated.

\section{Determination of the incidence of mitotic and BrdU-labeled cells}

Proliferative processes were assessed from the number of mitotic and BrdU-labeled cells. Mitoses were counted in sections stained with iron hematoxylin. BrdU was detected using immunohistochemical staining using an anti-BrdU mouse monoclonal antibody conjugated with alkaline phosphatase (Boehringer Mannheim GmbH, Mannheim, Germany) diluted to 1:20, as described (Gunin et al. 2000). Alkaline phosphatase activity was revealed through the use of naphtol AS-BI-phosphate and new fuchsin as chromogens. All results were expressed as the percentage of mitotic or labeled cells. The number of mitotic and BrdU-labeled cells in luminal epithelium, glandular epithelium, stromal cells and myometrial cells was counted as described (Gunin et al. 2001). At least 3000 
epithelial and 10000 stromal or myometrial cells were assessed per mouse. The percentage of mitotic or labeled cells was then calculated.

\section{Estrogen receptor- $\alpha$ and $\beta$-catenin}

Estrogen receptor- $\alpha$ and $\beta$-catenin were detected using routine indirect immunohistochemical staining. Rabbit anti-estrogen receptor- $\alpha$ polyclonal antibody (Santa Cruz Biotechnology Inc., Santa Cruz, CA, USA) diluted 1:50, and rabbit anti- $\beta$-catenin antiserum (Sigma Chemical Co.) diluted 1:50 were used as primary antibodies. Goat anti-rabbit immunoglobulin $G$ antibody conjugated with alkaline phosphatase (Jackson ImmunoResearch Laboratories Inc., West Grove, PA, USA) was used as the secondary antibody, and alkaline phosphatase activity was then revealed using naphtol AS-BI-phosphate and new fuchsin as chromogens. Control sections were stained in a similar manner, except that the primary antibody was replaced with normal rabbit serum. To avoid possible differences in the intensity of staining, sections from all mice were processed simultaneously, so that all sections were incubated in exactly the same TBS, the same mixture of primary and secondary antibodies, the same mixture for development of enzyme activity, and for the same times, and at the same temperature. Intensity of immunostaining was quantified by photometric measurement of optical density (D) for positively stained components of a tissue. Photometry was performed using a light microscope and an FMEL-1A microspectrophotometer (LOMO, St Petersburg, Russia) by measuring the intensity of light passing through equivalent areas occupied by positively stained structures $\left(\mathrm{F}^{+}\right)$and by structures with no staining $\left(\mathrm{F}^{-}\right)$. Optical density (light absorption) was calculated by the formula: $\mathrm{D}=\lg \left(\mathrm{F}^{+} / \mathrm{F}^{-}\right)$. In the case of estrogen receptors, positive staining was detected in the nuclei of all uterine tissues (luminal epithelium, glandular epithelium, stromal cells, myometrial cells). Therefore, the intensity of light passing through the nuclei $\left(\mathrm{F}^{+}\right.$; positive staining) and through the cytoplasm $\left(\mathrm{F}^{-}\right.$; negative staining) was measured. In the case of $\beta$-catenin, positive immunostaining was found in the cytoplasm of luminal and glandular epithelia, but not in endometrial stromal cells nor in myometrial cells. Consequently, the intensity of light passing through the cytoplasm of uterine epithelial cells $\left(\mathrm{F}^{+}\right.$; positive staining) and through the endometrial stromal cells $\left(\mathrm{F}^{-}\right.$; negative staining) was utilized. At least 100 nuclei were analyzed for each structure in each mouse.

\section{Statistics}

Arithmetic means and standard errors were calculated for each data group. The significance of differences was determined by nonparametric Mann-Whitney U-test (uterine weight, proliferation, estrogen receptors,
Table 1 Effect of treatment with estradiol and saline, bromocriptine, metoclopramide, or prolactin for 30 days on uterine weight. Values are means \pm S.E.M., $n=20$ mice in each group

Uterine weight

(mg per 100 g body weight)

\section{Treatment}

Estradiol and saline (control) Estradiol and bromocriptine Estradiol and metoclopramide Estradiol and prolactin

$758 \cdot 9 \pm 54 \cdot 7$

$913 \cdot 3 \pm 58 \cdot 4$

$782 \cdot 1 \pm 28 \cdot 2$

$669 \cdot 4 \pm 49 \cdot 6$

No significant difference in comparison to control $(P<0 \cdot 05)$ was revealed by Mann-Whitney U-test

$\beta$-catenin) and by use of the chi-square test (gland types, epithelium types, pathology). A value of $P<0.05$ was considered statistically significant.

\section{Results}

\section{Uterine weight}

There were no statistically significant changes in uterine weight (Table 1).

\section{Uterine histology}

Microscopical examination of uteri of ovariectomized mice which were not subjected to estrogen treatment revealed atropic endometrium in all cases independent of additional treatment with bromocriptine, metoclopramide, or prolactin. The endometrial glands in all these uteri had a narrow lumen, and a round, oval, or elongate shape, which is a microscopical reflection of simple tubular glands, regarded as normal. All glands were lined with simple cuboidal epithelium. In mice injected with estradiol together with saline, atypical glands, especially glands with daughter glands and glands forming conglomerates, were often observed (Fig. 1, Table 2). Glands lined with pseudostratified or stratified epithelium, which often contained atypical cells and nuclei, were also documented in a large percentage of cases (Fig. 1, Table 2). The histological analysis of the uteri is presented in Table 2 .

The uterine histology of mice administered both estradiol and bromocriptine differed from that of control animals which had received estradiol and saline. The number of normal glands was increased and the incidence of cystic glands was decreased. However, the number of glands with daughter glands and glands forming conglomerates was increased. The percentage of glands with pseudostratified or stratified epithelium was greater in animals receiving estradiol with bromocriptine. Also, the incidence of complex and atypical hyperplasia was increased (Table 2). 


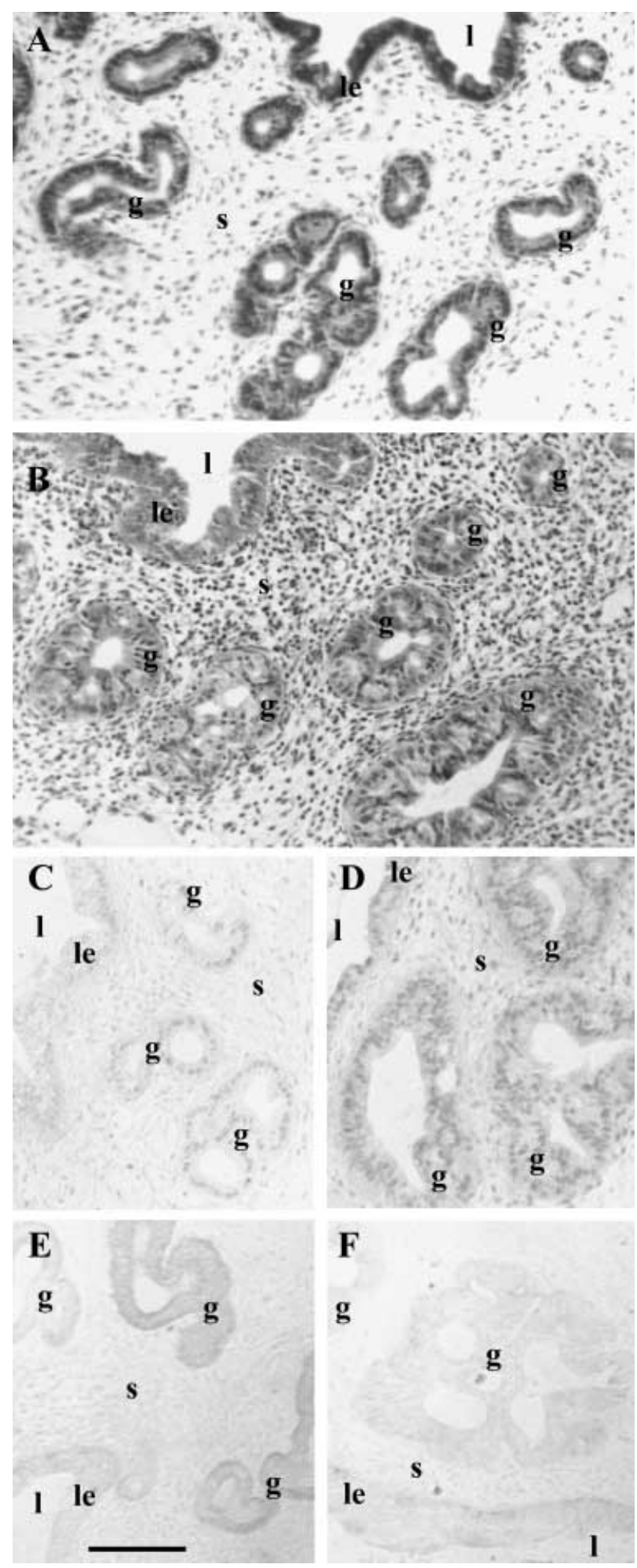

Journal of Endocrinology (2002) 172, 61-69
In mice treated with estradiol together with metoclopramide, the number of abnormal glands was decreased compared with that of control mice receiving estradiol and saline (Table 2). However, the number of glands with daughter glands was slightly higher than in controls. The incidence of glands with simple, pseudostratified and stratified epithelium was almost the same as in control animals. The incidence of cystic hyperplasia and complex hyperplasia was also similar to that of control mice. However, simple hyperplasia and atypical hyperplasia were diagnosed in a lower percentage of cases. Normal uterine histology was found in a greater percentage of cases in mice treated with estradiol and metoclopramide than in control animals receiving estradiol and saline (Table 2).

Treatment with estradiol and prolactin produced a decrease in the incidence of abnormal glands and in glands with pseudostratified or stratified epithelium. Also, the incidence of atypical hyperplasia was markedly reduced in animals receiving estradiol and prolactin (Fig. 1, Table 2).

\section{Proliferation}

The effect of treatments on proliferative processes in the uterus was assessed using the number of mitotic and BrdU-labeled cells. Treatment with estradiol together with bromocriptine produced an increase in the number of mitotic and BrdU-labeled cells in all uterine tissues (Table 3). However, some parameters such as the number of mitotic cells in myometrial cells, and the number of BrdU-labeled cells in luminal epithelium and stromal cells were not significantly changed (Table 3 ). The number of mitotic cells in mice treated with estradiol together with metoclopramide was decreased in all uterine structures (Table 3). However, the number of BrdU-labeled cells in these mice was decreased only in luminal epithelium and was almost unchanged in glandular epithelium, stromal cells and myometrial cells. Combined administration of

Figure 1 Photomicrographs demonstrating histological findings (A, $B)$, immunohistochemical staining for estrogen receptor- $\alpha(C, D)$ and $\beta$-catenin $(E, F)$ in the uterus of mice treated with estradiol with $(A, C, E)$ or without $(B, D, F)$ prolactin for 30 days. In $A$ (estradiol and prolactin), the uterine lumen (I) is lined with simple columnar epithelium, the endometrial glands are not enlarged, have normal (round or oval) shapes, and are lined with simple columnar or cuboidal epithelium. In B (estradiol and saline), there are glands with little daughter glands inside their walls; the glands are lined with pseudostratified or stratified columnar or cuboidal epithelium. le, luminal epithelium; g, glandular epithelium; s, stromal cells. (C and D) Estrogen receptor- $\alpha$ is seen in the nuclei of luminal epithelium (le), glandular epithelium (g) and stromal cells (s). The expression of estrogen receptor- $\alpha$ in all tissues is lower under treatment with estradiol and prolactin (C), than in controls (D). ( $E$ and F) Immunoreactivity of $\beta$-catenin is visible in luminal (I) and glandular (g) epithelia. Expression of $\beta$-catenin in epithelial components is higher under treatment with estradiol and prolactin $(\mathrm{E})$, compared with control mice treated with estradiol and saline (F). I, uterine lumen. Scale bar $50 \mu \mathrm{m}$. 
Table 2 Type of endometrial glands, type of glandular epithelium, and pathology diagnosis of the uteri of ovariectomized mice treated with estradiol and saline, bromocriptine, metoclopramide, or prolactin for 30 days. Values are means \pm S.E.M., $n=20$ mice in each group

\begin{tabular}{|c|c|c|c|c|}
\hline & $\begin{array}{l}\text { Estradiol and saline } \\
\text { (control) }\end{array}$ & $\begin{array}{l}\text { Estradiol and } \\
\text { bromocriptine }\end{array}$ & $\begin{array}{l}\text { Estradiol and } \\
\text { metoclopramide }\end{array}$ & $\begin{array}{l}\text { Estradiol and } \\
\text { prolactin }\end{array}$ \\
\hline \multicolumn{5}{|c|}{ Percentage of different types of glands in the uterus } \\
\hline Normal glands & $59 \cdot 28 \pm 7 \cdot 53$ & $66 \cdot 31 \pm 7 \cdot 05$ & $71 \cdot 06 \pm 7 \cdot 33$ & $80 \cdot 23 \pm 9 \cdot 08$ \\
\hline Cystic glands & $16 \cdot 49 \pm 4 \cdot 77$ & $5 \cdot 04 \pm 2 \cdot 55$ & $7 \cdot 64 \pm 3 \cdot 95$ & $3 \cdot 31 \pm 2 \cdot 47$ \\
\hline Glands with daughter glands & $14 \cdot 63 \pm 4 \cdot 18$ & $17 \cdot 67 \pm 3 \cdot 99$ & $16 \cdot 86 \pm 5 \cdot 08$ & $8 \cdot 13 \pm 3 \cdot 66$ \\
\hline $\begin{array}{l}\text { Conglomerate of glands } \\
\text { Chi-square test }\end{array}$ & $9 \cdot 6 \pm 4 \cdot 3$ & $\begin{array}{l}10 \cdot 98 \pm 4 \cdot 63 \\
P<0 \cdot 001\end{array}$ & $\begin{array}{l}\quad 4 \cdot 44 \pm 2 \cdot 71 \\
P<0 \cdot 001\end{array}$ & $\begin{aligned} 8 \cdot 33 \pm 6 \cdot 41 \\
P<0 \cdot 001\end{aligned}$ \\
\hline \multicolumn{5}{|c|}{ Percentage of glands with the type of epithelium in the uterus } \\
\hline Simple epithelium & $51 \cdot 62 \pm 8 \cdot 25$ & $40 \cdot 05 \pm 7 \cdot 14$ & $47 \cdot 29 \pm 7 \cdot 41$ & $68 \cdot 97 \pm 9 \cdot 11$ \\
\hline Pseudostratified epithelium & $23 \cdot 66 \pm 5 \cdot 52$ & $36 \cdot 81 \pm 5 \cdot 23$ & $27 \cdot 48 \pm 3.96$ & $15 \cdot 95 \pm 5 \cdot 21$ \\
\hline Stratified epithelium & $24 \cdot 72 \pm 7 \cdot 31$ & $23 \cdot 14 \pm 6 \cdot 82$ & $25 \cdot 23 \pm 7 \cdot 85$ & $15 \cdot 08 \pm 8 \cdot 81$ \\
\hline \multicolumn{5}{|c|}{ Pathology diagnosis (\% of cases) } \\
\hline Proliferative endometrium & 30 & 10 & 55 & 60 \\
\hline Simple hyperplasia & 20 & 25 & 5 & 20 \\
\hline Cystic hyperplasia & 5 & 0 & 5 & 0 \\
\hline Complex hyperplasia & 10 & 20 & 10 & 10 \\
\hline Atypical hyperplasia & 35 & 45 & 25 & 10 \\
\hline Chi-square test & & $P<0.001$ & $P<0.001$ & $P<0.001$ \\
\hline
\end{tabular}

The significance of differences was calculated by comparison with control mice treated with estradiol and saline (chi-sqaure test).

estradiol and prolactin decreased both proliferative parameters in all uterine structures (Table 3 ). It should be noted that the changes in the number of BrdU-labeled cells in glandular epithelium, stromal and myometrial cells seen in mice treated with estradiol and prolactin were not statistically significant.

\section{Estrogen receptor- $\alpha$}

The levels of estrogen receptor- $\alpha$ were increased in all uterine tissues of mice treated with estradiol together with bromocriptine, as compared with those of mice treated with estradiol and saline (Fig. 1, Table 4). In animals receiving estradiol and prolactin or metoclopramide, expression of estrogen receptor- $\alpha$ was lower in all uterine compartments compared with treatment with estradiol and vehicle (Fig. 1, Table 4). However, changes in estrogen receptor- $\alpha$ expression in glandular epithelium and myometrial cells in mice receiving estradiol and prolactin were not statistically significant.

\section{$\beta$-Catenin}

Immunoreactivity of $\beta$-catenin was found in luminal and glandular epithelia, whereas no clear positive staining was found in stromal and myometrial cells (Fig. 1, Table 4). The level of $\beta$-catenin in luminal and glandular epithelia was lower in animals treated with estradiol and bromocriptine and insignificantly higher after treatment with estradiol together with metoclopramide or prolactin (Fig. 1, Table 4).

\section{Control groups with no estrogen treatment}

Mice receiving olive oil instead of estradiol together with bromocriptine, prolactin, metoclopramide, or saline for 30 days were also used as controls. There were no detectable changes produced by olive oil or drugs in all parameters examined in all uterine tissues.

\section{Discussion}

Three experimental approaches were used to reveal the role of prolactin in the development of estrogendependent processes in the uterus. Injection of exogenous prolactin, that produces hyperprolactinemia (Kawagoe \& Hiroi 1989), was used as a first approach. The second model, administration of the $\mathrm{D}_{2}$-dopaminergic antagonist metoclopramide, which is well known to induce hyperprolactinemia (Marubayashi et al. 1989), was utilized. Treatment with bromocriptine, which is a well known and widely used $\mathrm{D}_{2}$-dopaminergic agonist inducing a marked reduction in prolactin synthesis and secretion (Advis et al. 1981, Kawagoe \& Hiroi 1989, Woods et al. 1998) was employed as the third experimental approach. Thus, one hypoprolactinemic and two hyperprolactinemic situations were designed.

It was shown that coadministration of prolactin to estrogen-treated mice decreased both uterine weight and proliferation, but bromocriptine had the opposite effect. Therefore, the effects of these treatments may be due to a decrease in the number of uterine cells. Metoclopramide decreased proliferation, but slightly increased uterine 


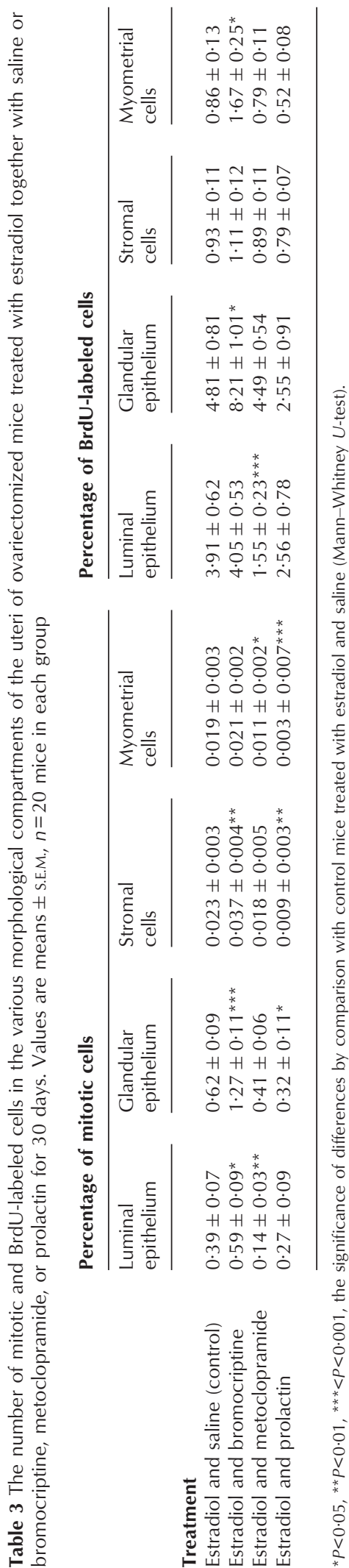


Table 4 Expression of estrogen receptor- $\alpha$ and $\beta$-catenin in uterine tissues of mice treated with estradiol together with saline, bromocriptine, metoclopramide, or prolactin for 30 days. Values are means \pm S.E.M., $n=20$ mice in each group

Estrogen receptor- $\alpha$ (level of expression)

\begin{tabular}{|c|c|c|c|c|c|}
\hline $\begin{array}{l}\text { Luminal } \\
\text { epithelium }\end{array}$ & $\begin{array}{l}\text { Glandular } \\
\text { epithelium }\end{array}$ & $\begin{array}{l}\text { Stromal } \\
\text { cells }\end{array}$ & $\begin{array}{l}\text { Myometrial } \\
\text { cells }\end{array}$ & $\begin{array}{l}\text { Luminal } \\
\text { epithelium }\end{array}$ & $\begin{array}{l}\text { Glandular } \\
\text { epithelium }\end{array}$ \\
\hline $0 \cdot 12 \pm 0 \cdot 007$ & $0 \cdot 14 \pm 0 \cdot 01$ & $0 \cdot 17 \pm 0 \cdot 01$ & $0 \cdot 12 \pm 0 \cdot 005$ & $0 \cdot 04 \pm 0.002$ & $0 \cdot 08 \pm 0 \cdot 004$ \\
\hline $0 \cdot 15 \pm 0.009^{*}$ & $0 \cdot 16 \pm 0.006^{* *}$ & $0 \cdot 22 \pm 0 \cdot 1^{* *}$ & $0 \cdot 15 \pm 0.006^{* *}$ & $0.03 \pm 0.002^{* *}$ & $0.05 \pm 0.002^{* *}$ \\
\hline $0.09 \pm 0.006^{*}$ & $0 \cdot 11 \pm 0 \cdot 008^{*}$ & $0 \cdot 13 \pm 0.005^{* *}$ & $0 \cdot 1 \pm 0 \cdot 004^{*}$ & $0.05 \pm 0.003$ & $0 \cdot 08 \pm 0.004$ \\
\hline $0.09 \pm 0.006^{*}$ & $0 \cdot 12 \pm 0.009$ & $0 \cdot 12 \pm 0 \cdot 01^{*}$ & $0 \cdot 11 \pm 0 \cdot 008$ & $0.05 \pm 0.004$ & $0.09 \pm 0.006$ \\
\hline
\end{tabular}

\section{Treatment}

Estradiol and saline (control) Estradiol and bromocriptine Estradiol and metoclopramide Estradiol and prolactin

${ }^{*} P<0 \cdot 05,{ }^{* *} P<0 \cdot 01$, the significance of differences by comparison with control mice treated with estradiol and saline (Mann-Whitney $U$-test). The quantitiation of immunostaining for estrogen receptor- $\alpha$ and $\beta$-catenin was performed by determination of optical density $\left(\mathrm{D}=\lg \left(\mathrm{F}^{-} / \mathrm{F}^{+}\right)\right)$for positive stained components of a tissue by measuring the intensity of light passing through equivalent areas occupied by positive stained structures $\left(\mathrm{F}^{+}\right)$and by structures with no staining $\left(\mathrm{F}^{-}\right)$. In the case of estrogen receptors, the intensity of light passing through the nuclei $\left(\mathrm{F}^{+}\right.$; positive staining) and through the cytoplasm $\left(\mathrm{F}^{-}\right.$; negative staining) was measured. In the case of $\beta$-catenin, the intensity of light passing through the cytoplasm of uterine epithelial cells $\left(\mathrm{F}^{+}\right.$; positive staining) and through the endometrial stromal cells ( $\mathrm{F}^{-}$; negative staining) was utilized. The value of optical density was used as the level of expression.

weight, a parameter which probably depends on the water content in the uterus of estrogen-treated mice. Our results indicate that prolactin produces marked reductions in these estrogen-induced morphogenetic changes in the uterus. Metoclopramide produces results similar to those with prolactin, but much less expressed. Bromocriptine has an effect on estrogen-dependent uterine morphogenesis which is opposite to that of prolactin or metoclopramide. Chronic treatment with prolactin or metoclopramide for 30 days causes a decrease in estradiol-induced proliferation, as assessed by the number of mitotic and BrdU-labeled cells, indicating that the number of cells in the $S$ and $M$ phases of the cell cycle is reduced in the uterine tissues. Again, bromocriptine produces an opposite effect. The present results are in agreement with previous observations, where acute (not chronic) estrogen treatment was utilized (Saiduddin \& Zassenhaus 1977, Hernandez \& Alvarez 1980, Kauli et al. 1985, Negami \& Tominaga 1991, Gunin 1996, Spritzer et al. 1996).

Thus, prolactin or metoclopramide produce a reduction in almost all estrogen-dependent processes in the uterus. Moreover, prolactin turns the estrogen-dependent changes from the direction of precancerous, atypical hyperplasia formation to the more favorable situation where normal proliferative endometrium or simple hyperplasia is present. In the case of bromocriptine, there is increased expression of all estrogen-dependent parameters in the uterus. The effects of prolactin and dopaminergic drugs on morphogenetic processes in the uterus are probably brought about by changes in proliferation, cell differentiation and apoptosis activity. The effect of prolactin is most likely mediated via prolactin receptors, the presence of these in the uterus being well documented (Ohno 1982, Rose et al. 1993). These results suggest that the effects of metoclopramide and bromocriptine on estrogen-dependent processes in the uterus are mediated, at least partially, via changes in prolactin level in the organism. However, the effect of metoclopramide is close to, but not exactly the same as, that of prolactin, while the action of bromocriptine is almost but not exactly opposite to that of prolactin. Therefore, a direct effect of the drugs on the uterus cannot be excluded. It is also interesting to note that all the treatments have an effect on parameters tested only in estrogen-treated mice and are not found in control animals receiving olive oil instead of estradiol. This situation suggests that all treatments used affect some steps in the mechanism of estrogen action. It is also possible that estradiol is needed to induce prolactin receptors in the uterus.

To clarify some of the possible pathways involved in the development of the morphological effects reported here, the expression of estrogen receptor- $\alpha$ and $\beta$-catenin in the uterus was examined.

It is shown here that the levels of estrogen receptor- $\alpha$ were lower in all uterine compartments in animals receiving estradiol and prolactin or metoclopramide, and were higher after treatment with estradiol and bromocriptine. Hence, estrogen receptor $\alpha$ is associated with shifts in uterine weight, proliferation and morphogenesis, that have resulted from treatment with prolactin and the dopaminergic drugs used. Previous studies also showed that prolactin reduced estrogen receptor levels in uterine cells (Saiduddin \& Zassenhaus 1977, Tamaya et al. 1988). It should be noted that the levels of estrogen receptor- $\alpha$ were not altered significantly in the uterine tissue under any of the treatments used. Therefore, the suggested mechanism of action probably has a cell specific character.

$\beta$-Catenin is a final component of the Wnt pathway which inhibits the activity of glycogen-synthase kinase-3 $\beta$ followed by an increase in the level of $\beta$-catenin (Fujimoto et al. 1996, Jan \& Jan 2000). Then, $\beta$-catenin enters the nucleus, changing the activity of specific genes, which is followed by shifts in cell behavior such as changes in 
proliferation, cell shape, cell movement and adhesion (Miller et al. 1999, Schlesinger et al. 1999). Synthesis and content of $\beta$-catenin in the uterus have been shown to be affected by estrogen hormones (Fujimoto et al. 1996, 1998). Moreover, it has been shown that $\beta$-catenin plays a role in the formation of endometrial cancer (Nei et al. 1999, Kitajewski \& Sassoon 2000), and the level of $\beta$-catenin in the uterus is negatively correlated with the degree of tumour differentiation and good prognosis (Fujimoto et al. 1998, Miyamoto et al. 2000). Here we show that uterine expression of $\beta$-catenin is increased under estradiol and prolactin or metoclopramide treatments. At the same time, estrogen-dependent proliferation and morphogenetic changes are less expressed. The opposite situation occurs in the case of bromocriptine. Hence, it can be suggested that prolactin and dopaminergic drugs act on estrogen-dependent processes in the uterus by changing $\beta$-catenin levels. Other workers have also proposed that $\beta$-catenin is involved in estrogen-dependent changes in uterine morphology and hyperplasia formation (Fujimoto et al. 1998, Miyamoto et al. 2000).

Thus, this research provides evidence that prolactin diminishes estrogen action and prevents the development of estrogen-dependent endometrial hyperplasia. Estrogen receptor- $\alpha$ and $\beta$-catenin are associated with the effects observed. We hope that this research will lead to a better understanding of the origin and progression of estrogen-dependent cancer of the female reproductive system.

\section{Acknowledgements}

This work was partially supported by grants from the Russian Foundation for Basic Research (00-04-48043), from the President of Russian Federation for Young Doctors in Science (00-15-99365). We are most grateful to $\operatorname{Dr}$ A F Parlow, National Hormone and Pituitary Program, Harbor-UCLA Medical Center, Torrance, CA, USA) for ovine prolactin. We sincerely thank Dr Vladimir Botchkarev (Department of Dermatology, Boston University Medical School, Boston, USA) for reagents and for helpful comments on the manuscript.

\section{References}

Advis JP, White SS \& Ojeda SR 1981 Delayed puberty induced by chronic suppression of prolactin release in the female rat. Endocrinology 109 1321-1330.

Barnes AE, Crissman JD, Azoury RS \& Schneider DP 1981 Association of a prolactin-secreting pituitary microadenoma and endometrial carcinoma. Obstetrics and Gynecology 58 391-394.

Borgundvaag B, Kudlow JE, Mueller SG \& George SR 1992 Dopamine receptor activation inhibits estrogen-stimulated transforming growth factor-alpha gene expression and growth in anterior pituitary, but not in uterus. Endocrinology 130 3453-3458.
Couse JF \& Korach KS 1999 Estrogen receptor null mice: what have we learned and where will they lead us? Endocrine Reviews 20 358-417.

Deligdisch L 2000 Hormonal pathology of the endometrium. Modern Pathology 13 285-294.

Dexeus S \& Barri PN 1998 Hyperprolactinemia: an inductor of neoplastic changes in endometrium? A report of two cases. Gynecological Endocrinology 12 273-275.

Emons G, Fleckenstein G, Hinney B, Huschmand A \& Heyl W 2000 Hormonal interactions in endometrial cancer. Endocrine Related Cancer 7 227-242.

Falsetti L, Omodei U, Dordoni D, Scagliola P, Turla R, Zotti L \& Archetti L 1983 Profiles and endocrine correlations in endometrial carcinoma. European Journal of Gynaecological Oncology 4 30-34.

Fujimoto J, Ichigo S, Hori M \& Tamaya T 1996 Alteration of E-cadherin, alpha- and beta-catenin mRNA expression in human uterine endometrium during the menstrual cycle. Gynecological Endocrinology 10 187-191.

Fujimoto J, Ichigo S, Hori M \& Tamaya T 1998 Expressions of E-cadherin and alpha- and beta-catenin mRNAs in uterine endometrial cancers. European Journal of Gynaecological Oncology 19 $78-81$.

Gunin A 1996 The role of prolactin in realization of estradiol action in the uterus of ovariectomized rats. European Journal of Obstetrics and Gynecology and Reproductive Biology 64 119-127.

Gunin A 1998 Effect of long-term glucocorticoid treatment on oestradiol-induced proliferation in the uterus of ovariectomized rats. Journal of Endocrinology 157 481-488.

Gunin AG, Sharov AA \& Nikolaev DV 2000 Two month glucocorticoid treatment increases estradiol-induced stromal and myometrial cell proliferation in the uterus of ovariectomized rats. European Journal of Obstetrics and Gynecology and Reproductive Biology 88 171-179.

Gunin AG, Mashin IN \& Zakharov DA 2001 Proliferation, mitosis orientation and morphogenetic changes in the uterus of mice following chronic treatment with both estrogen and glucocorticoid hormones. Journal of Endocrinology 169 23-31.

Hernandez DE \& Alvarez EO 1980 Effect of administration of dopaminergic agonists on the uterine responsiveness to oestrogen in maturing rats. Journal of Endocrinology 86 383-386.

Imai A, Furui T, Ohno T, Matsunami K, Takahashi K \& Tamaya T 1993 Prolactin binds to human endometrial fibroblasts and inhibits mitogenicity of an endometrial carcinoma extract. Proceedings of the Society for Experimental Biology and Medicine 203 117-122.

Jan YN \& Jan LY 2000 Polarity in cell division: What frames thy fearful asymmetry? Cell 100 599-602.

Kauli R, Schoenfeld A, Ovadia Y, Math S, Assa S \& Laron Z 1985 Delayed puberty and hypoplastic uterus associated with hyperprolactinemia: successful treatment with bromocriptine. Hormone Research 22 68-73.

Kawagoe S \& Hiroi M 1989 Further evidence that prolactin controls the prepubertal sexual development in the female rat. Gynecologic and Obstetric Investigation 27 197-200.

Kelly MA, Rubinstein M, Asa SL, Zhang G, Saez C, Bunzow JR, Allen RG, Hnasko R, Ben-Jonathan N, Grandy DK \& Low MJ 1997 Pituitary lactotroph hyperplasia and chronic hyperprolactinemia in dopamine D2 receptor-deficient mice. Neuron 19 103-113.

Kimura J, Kato Y, Hirose T \& Okada H 1986 Growth promotion of human endometrial adenocarcinoma cell line HHUA by prolactin. Nippon Sanka Fujinka Gakkai Zasshi 38 1779-1780.

Kiss R, de Launoit Y, L'Hermite Baleriaux M, L'Hermite M, Paridaens RJ, Danguy AJ \& Pasteels JL 1987 Effect of prolactin and estradiol on cell proliferation in the uterus and the MXT mouse mammary neoplasm. Journal of the National Cancer Institute $\mathbf{7 8}$ 993-998. 
Kitajewski J \& Sassoon D 2000 The emergence of molecular gynecology: homeobox and Wnt genes in the female reproductive tract. Bioessays 22 902-910.

Lipsett MB 1983 Hormones, medications, and cancer. Cancer $\mathbf{5 1}$ 2426-2429.

Lucas WE \& Yen SS 1979 A study of endocrine and metabolic variables in postmenopausal women with endometrial carcinoma. American Journal of Obstetrics and Gynecology 134 180-186.

Marchesoni D, Gangemi M, Maggino T, Paternoster D, Mozzanega B, Sormani Zodo F \& Vincenti E 1982 Hormonal profile following total abdominal hysterectomy and bilateral salpingo-oophorectomy in post-menopausal endometrial carcinoma. Clinical Experiments in Obstetrics and Gynecology 9 238-242.

Martin L, Finn CA \& Trinder G 1973 Hypertrophy and hyperplasia in the mouse uterus after oestrogen treatment: an autoradiographic study. Journal of Endocrinology 56 133-144.

Marubayashi U, McCann SM \& Antunes-Rodrigues J 1989 Altered gonadotropin and prolactin release induced by median eminence (ME) lesions and pharmacological manipulation of prolactin release: further evidence for separate hypothalamic control of FSH and LH release. Brain Research Bulletin 23 193-200.

Miller JR, Hocking AM, Brown JD \& Moon RT 1999 Mechanism and function of signal transduction by the Wnt/beta-catenin and Wnt/Ca ${ }^{2+}$ pathways. Oncogene $187860-7872$.

Miyamoto S, Baba H, Kuroda S, Kaibuchi K, Fukuda T, Maehara Y \& Saito T 2000 Changes in E-cadherin associated with cytoplasmic molecules in well and poorly differentiated endometrial cancer. British Journal of Cancer 83 1168-1175.

Negami AI \& Tominaga T 1991 Effects of prolactin on cultured human endometrial cells. Hormone Research 35 (Suppl 1) 50-57.

Nei H, Saito T, Yamasaki H, Mizumoto H, Ito E \& Kudo R 1999 Nuclear localization of beta-catenin in normal and carcinogenic endometrium. Molecular Carcinogenesis 25 207-218.

Ohno Y 1982 Studies on the interaction of prolactin and estrogen in rabbit ovary and uterus. Nippon Sanka Fujinka Gakkai Zasshi 34 252-260.

Ristic PI, Ory SJ \& Lurain JR 1986 Endometrial adenocarcinoma associated with drug-induced hyperprolactinemia. Obstetrics and Gynecology 67 86S-88S.

Rose J, Huang JL \& Mead RA 1993 Role of ovarian steroids in development of uterine binding sites for prolactin in the ferret. Biology of Reproduction 48 1266-1273.
Saiduddin S \& Zassenhaus HP 1977 Effect of prolactin on specific oestradiol receptors in the rat uterus. Journal of Endocrinology 72 101-102.

Schlesinger A, Shelton CA, Maloof JN, Meneghini M \& Bowerman B 1999 Wnt pathway components orient a mitotic spindle in the early Caenorhabditis elegans embryo without requiring gene transcription in the responding cell. Genes and Development 13 2028-2038.

Scully RE, Bonfiglio TA, Kurman RJ, Silverberg SG \& Wilkinson EJ 1994 Histological Typing of Female Genital Tract Tumours (International Histological Classification of Tumours), pp 13-18, edn 2. Geneva: WHO.

Shaban MA \& Terranova PF 1986 2-Bromo-alpha-ergocryptine mesylate (CB-154) inhibits prolactin and luteinizing hormone secretion in the prepubertal female rat. Biology of Reproduction 34 788-795.

Silverberg SG 2000 Problems in the differential diagnosis of endometrial hyperplasia and carcinoma. Modern Pathology 13 309-327.

Singtripop T, Mori T, Park MK, Sakamoto S \& Kawashima S 1991 Development of uterine adenomyosis after treatment with dopamine antagonists in mice. Life Sciences 49 201-206.

Spritzer PM, Ribeiro MF, Oliveira MC, Barbosa-Coutinho LM, Silva IS, Dahlem N, Cericatto R \& Pavanato MA 1996 Effects of tamoxifen on serum prolactin levels, pituitary immunoreactive prolactin cells and uterine growth in estradiol-treated ovariectomized rats. Hormone and Metabolic Research 28 171-176.

Tamaya T, Arabori K \& Okada H 1988 Relation between steroid receptor levels and prolactin level in the endometrial stromal cells. Acta Obstetrica et Gynecologica Scandinavica 67 265-269.

Tolino A, Di Serio C, Caracciolo GB, Tartaglia E \& Riccio S 1991 The role of prolactin in endometrial lesions. Minerva Ginecology 43 495-497.

Woods KA, Buechi KA, Illig AM \& Badura LL 1998 Norepinephrine content in the paraventicular nucleus of the hypothalamus as a function of photoperiod and dopaminergic tone. Endocrine 8 79-83.

Ylikorkala O, Kauppila A \& Rajala T 1979 Pituitary gonadotrophins and prolactin in patients with endometrial cancer, fibroids or ovarian tumours. British Journal of Obstetrics and Gynaecology 86 901-904.

Received 6 September 2001 Accepted 10 September 2001 